ISSN: 1641-4713; e-ISSN: 2081-1160

DOI: https://doi.org/10.36551/2081-1160.2020.25.175-208

\title{
Reconstrução social da agricultura no Rio de Janeiro: um estudo sobre o Vale do São João
}

\author{
Social Reconstruction of Agriculture in Rio de Janeiro: \\ a Study About the São João Valley
}

Ana Maria Motta Ribeiro

Programa de Pós-Graduação em Sociologia e Direito (PPGSD) Departamento de Sociologia, Universidade Federal Fluminense (UFF), Brasil ORCID ID: https://orcid.org/0000-0003-2761-3539

E-mail: anamribeiro@outlook.com

Rodolfo Bezerra de Menezes Lobato da Costa Programa de Pós-Graduação em Meio Ambiente e Desenvolvimento (PPGMADE) Departamento de Sociologia, Universidade Federal do Paraná (UFPR), Brasil ORCID ID: https://orcid.org/0000-0001-6304-3831

E-mail: rodolfolobato@hotmail.com

Recepción: 13.01.2020

Aprobación: 7.05.2020

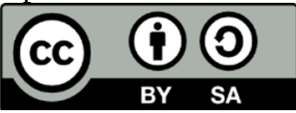

Resumo: O artigo desenvolve um debate sobre a reconstrução social da agricultura no estado do Rio de Janeiro, através de um caso empírico, a comunidade rural de Sebastião Lan II. A partir de uma releitura histórica do território do Vale do Rio São João, no interior fluminense, tecemos relações entre o processo de mudança dos ciclos socioeconômicos no território com a crise ambiental e a concentração de terras. Refletiremos sobre conceitos emergentes na relação entre a pesquisa empírica e teórica, em especial as noções de "desagriculturalização" e "rerruralização". A pesquisa foi desenvolvida em projetos de extensão e assessoria sociojurídica aos movimentos sociais em luta pela reforma agrária e pela democratização do acesso à terra. Tentaremos refletir sobre a noção de reprodução social da agricultura enquanto um sintoma de conflitos sociais, através do qual identificaremos sinais de resistência contra injustiças socioambientais.

Palavras chave: reforma agrária, Rio de Janeiro, agricultura, conflito fundiário, Sebastião Lan. 


\begin{abstract}
The article develops a debate about the social reconstruction of agriculture in the state of Rio de Janeiro, through an empirical case, the rural community of Sebastião Lan II. From a historical rereading of the territory of the São João River Valley, we weave relationships between the process of changing socioeconomic cycles in the territory with the environmental crisis and land concentration. We will reflect on emerging concepts in the relationship between empirical and theoretical research, in particular the notions of "desagriculturalização" and "rerruralização". The research was developed in extension projects and socio-legal advice to social movements fighting for land reform and democratization of access to land. We will try to reflect on the notion of social reproduction of agriculture as a symptom of social conflicts, through which we will identify signs of resistance against socio-environmental injustices.
\end{abstract}

Keywords: agrarian reform, Rio de Janeiro, agriculture, land conflict, Sebastião Lan.

\title{
1. INTRODUÇÃO
}

Neste artigo pretendemos analisar diferentes contextos da reconstrução social da agricultura no interior do estado do Rio de Janeiro (Brasil), mais especificamente no Vale do São João, por onde seus habitantes assistiram e resistiram a projetos de colonização, abandono, modernização e reocupação. De tal universo destacaremos a história da comunidade rural de Sebastião Lan II, cujos traços "genéticos" são também uma síntese de acontecimentos passados e presentes.

Tentaremos compreender a origem da luta desses trabalhadores rurais como caso empírico, através do qual localizaremos um devir histórico. Por origens genéticas nos apropriamos da percepção de Bourdieu (2014), que enfatiza três cuidados metodológicos: a necessidade de saber o que é historicamente construído - sem naturalização; segundo, que há lógicas específicas dos processos sociais - que por vezes se diferenciam da lógica clássica, formal e pretensamente universal; e, por último, que o objeto de estudo da sociologia é "provisório, não aleatório e não necessário, de uma relação entre uma estrutura que é produto da história, um campo, e uma estrutura incorporada que é também o produto da história" (Bourdieu, 2014: 139).

Assim, encontramos trabalhadores rurais que ocuparam uma área pertencente à União, que havia sido grilada por um fazendeiro para desenvolvimento de uma agricultura em larga escala, o que ocasionou um intenso desmatamento e alterou o curso de rios e a própria formação "natural" do território. Sob a bandeira "Ocupar, Produzir e Resistir", os sem terras criaram um território o qual deram o nome de Sebastião Lan II, e, assim, iniciaram uma construção social - ainda em curso - que pode ser definida como uma experiência de democratização do acesso à terra, à moradia e ao trabalho. 
O caso envolve uma relação entre os conflitos socioambientais e a reforma agrária no estado do Rio de Janeiro, que revelou uma possibilidade real de produção de conhecimentos a partir da permanência de um coletivo de trabalhadores rurais por mais de duas décadas, em situação de acampamento. A área onde se encontra a comunidade rural Sebastião Lan II, chamada de Brejão, localiza-se entre as cidades de Casimiro de Abreu e Silva Jardim, interior do Estado do Rio de Janeiro. Em 1997, a conquista dessa terra foi conduzida em conjunto pelo Movimento dos Trabalhadores Rurais Sem Terra (MST) e pelo sindicalismo rural.

Ao mesmo tempo que permitiu a reintegração de uma área grilada para a União, colocou em evidência a articulação entre uma lógica produtivista e uma lógica preservacionista. Vizinhos de uma Reserva Biológica que tem como finalidade a preservação do mico-leão dourado, tentaremos destacar as diferentes dinâmicas impostas e os constrangimentos ambientais sob os quais esses trabalhadores foram e são obrigados a conviver.

O estudo do caso justifica-se pela longevidade do conflito, pela interseção entre diferentes campos (jurídico, político, econômico, agrário e ambiental) e, principalmente, pelo acompanhamento da trajetória dos agentes sociais pela Universidade Federal Fluminense (UFF), por cerca de 16 anos de forma intermitente. Essa presença ocorreu através da atuação formalizada em projetos de pesquisa e de extensão universitária, na condição de uma assessoria sociojurídica, o que corresponde às práticas do Observatório Fundiário Fluminense (OBFF) e do GT Ecosocial, núcleos de pesquisa e extensão de caráter interdisciplinar, voltados para a formação de investigadores de campo e de assessoria aos movimentos sociais organizados.

Os trabalhadores rurais sem-terra passaram a se constituir enquanto uma comunidade rural que vive a ambiguidade de ser reconhecida enquanto tal e é, simultaneamente, marginalizada dos principais processos decisórios dos quais são ou deveriam ser beneficiárias. Eis que a mudança da posição social que permitiria a regularização fundiária do território para constituição de um Projeto de Desenvolvimento Sustentável (PDS), uma exigência do Estado para qualificá-los como assentados. Fato que sintetizou uma proposta de reforma agrária que contrariava a prática cotidiana e a experiência com a terra em curso. Mais do que questionarmos os limites da regularização fundiária e as dificuldades da implementação de um projeto de reforma agrária, nesse artigo procuraremos compreender os sentidos e movimentos dos ciclos de reconstrução social da agricultura nesse território. 


\section{Metodologia}

A presença da Universidade, apesar de conduzida ao longo de quase duas décadas de modo intermitente, teve dois momentos mais relevantes e duas formas diferenciadas de pesquisa e extensão universitária. Esse recorte faz-se necessário para que se possa compreender o lugar de pertencimento diante da comunidade, através das formas pelas quais foram sendo conduzidas as duas mais significativas modalidades de pesquisa-ação ${ }^{1}$. As motivações de intervenção e a entrada nessa história colaboraram na mudança de sua identidade e comprometimento. E, dialeticamente, permitiu à Universidade repensar seu lugar nessa relação ao longo desses anos.

No ano de 2002, a Universidade Federal Fluminense (UFF) fica em evidência como agente harmonizador de um conflito, autorizado a pedido dos Ministérios do Meio Ambiente (MMA) e do Desenvolvimento Agrário (MDA) para solucionar o conflito entre o Instituto Brasileiro do Meio Ambiente e dos Recursos Renováveis (Ibama) e o Instituto Nacional de Colonização e Reforma Agrária (Incra). Para atender essa demanda, a reitoria da UFF formou uma equipe através de uma norma de serviço, que formalizou o GT Ecosocial. Enquanto universidade, nesta oportunidade, realizamos então o processo de gestação de um Laudo Multidisciplinar ${ }^{2}$, ouvindo todos os atores em conflito em suas diferentes versões, mas a partir de um lugar acadêmico especializado. O caráter da pesquisa e extensão desenvolvidas o tornavam indissociáveis dos seus efeitos políticas, que culminou com a assinatura de um Termo de Ajustamento de Conduta (TAC).

Depois, em 2013 (passados dez anos da primeira pesquisa), fomos convidados pelo Incra para acompanhar uma reunião formal, com a presença de autoridades técnicas e do próprio superintendente regional do Instituto, no sentido de viabilizar o Projeto de Desenvolvimento Sustentável (PDS) Sebastião Lan II. Mas a dinâmica social, conflitos entre o Incra e a comunidade rural em questão, evidenciou efeitos "negativos" que colocavam em risco um processo de assentamento que respeitasse a trajetória de conquista da terra e os investimentos

\footnotetext{
${ }^{1}$ Pesquisa Participante ou Pesquisa-Ação, sistematizada por Carlos Rodrigues Brandão (1981), constitui uma abordagem que nos permitiu levantar dados da realidade e intervir nela, agindo no sentido de alcançar contradições e provocar redefinições a partir da sugestão de temas de reflexão. A linha principal de pesquisa esteve sempre referendada na revelação de elementos e determinações subjacentes, considerando conflitos sociais como elemento indispensável no processo social.

${ }^{2}$ Produzido de forma interdisciplinar entre professores dos cursos de Direito (Wilson Madeira Filho), Sociologia (Ana Maria Motta Ribeiro), Engenharia Agrícola (Dario Prata) e Geografia (Mônica Cox).
} 
realizados ao longo de duas décadas de ocupação da área. Atualmente, em 2019, a comunidade rural de Sebastião Lan continua sem a devida regularização fundiária, formalmente classificada como uma ocupação.

Neste artigo tentamos compreender a formação social preexistente ao conflito contemporâneo, assim como o processo de reocupação das terras. Como instrumentos de reflexão para traduzir o caso empírico ao processo de reprodução social da agricultura, acionaremos os conceitos de desterritorialização, reterritorialização e extraterritorialidade, proposto por Haesbaert (2004). Contemplamos uma história social do Vale do São João sob a ótica de um movimento circular ou pendular de ocupação, expulsão e reocupação das terras. Trata-se de um cenário dinâmico, composto por inúmeros conflitos acumulados historicamente e que envolvem populações originárias, tradicionais e camponesas, numa luta constante contra os desafios do meio ambiente, do latifúndio e da devastação (Dean, 1996; Lamego, 1945, 1946).

Encontramos acordo com a periodização construída por Novicki (1994), que divide o mundo rural fluminense em três períodos: pré-1964 (politização); 1964-1978, despolitização autoritária; e pós-1979, repolitização. Essa periodização será reelaborada a partir de conceitos que emergiram durante a elaboração da pesquisa. Assim, desenvolveremos os conceitos de "desagriculturalização" e "rerruralização" (Madeira Filho et al., 2007; Ribeiro, 2005) do Vale do São João, refletindo sobre os efeitos de sua "modernização" (Binzstock, 1998; Graziano da Silva, 1982; Palmeira, 1989). A eleição da agricultura como uma vocação nacional na primeira metade do século XX (Mendonça, 1997) relaciona-se no estudo do caso com o ingresso de grandes proprietários e empresas na região (Geiger \& Mesquita, 1956).

Sobre o deslocamento populacional e as violências sofridas pelos agricultores e posseiros da década de 1950 até o período ditatorial (1964-1985), utilizamos como fonte de dados documentos do Núcleo de Pesquisa, Documentação e Referência sobre Movimentos Sociais e Políticas Públicas no Campo (NMSPP), sob coordenação da professora Leonilde Servolo de Medeiros (CPDA/UFRRJ) ${ }^{3}$. Elementos que se somaram a um clipping ${ }^{4}$ para contextualizar a "modernização" do Vale do São João como uma ação coordenada entre uma agricultura conven-

\footnotetext{
${ }^{3}$ A pesquisa contou com a colaboração do pesquisador Fabrício Teló, que disponibilizou fichas, entrevistas e relatórios do NMSPP/CPDA/UFRRJ.

${ }^{4}$ Utilizamos como ferramenta de pesquisa o acervo da Biblioteca Nacional, que digitalizou as edições do Jornal do Brasil do período citado de referência para o artigo. (https://www.bn.gov.br/explore/acervos/bndigital)
} 
cional e a construção de unidades de conservação de proteção integral (em especial a Reserva Biológica de Poço das Antas).

Desse contexto de conflitos, surgiu, finalmente, em 1997, o acampamento que deu origem posteriormente à comunidade rural de Sebastião Lan II. Assim, fez-se necessário algumas linhas para repensar as características do movimento social de luta pela terra no Estado do Rio de Janeiro, recriando um modo de ser "camponês" (Medeiros \& Leite, 1999). O "cercamento" das terras do Vale do São João pelos grandes proprietários, que acabaram constituindo um território para latifundiários (Ribeiro, 2007), significou uma nova etapa para os "ciclos de concentração fundiária e ciclos de desconcentração, sem que essa alternância seja interrompida por alterações radicais no regime de propriedade" (Martins, 2003: 28).

Estamos nos referindo a um movimento específico de trabalhadores rurais do estado do Rio de Janeiro, ocorrido mais especificamente no Vale do Rio São João, popularmente tratado como o Vale do São João. Neste artigo, trabalharemos com a noção de Vale do São João, que envolve os municípios de Silva Jardim, Casimiro de Abreu, Araruama e Cabo Frio.

As lutas por terra e os processos de expropriação aparentemente vem a se sintetizar numa economia moderna de mercado, uma ilusória linearidade lógica (teleológica). Trata-se de um problema sobre a gênese do capitalismo, ou da chamada acumulação primitiva, ou seja, a origem dos processos que foram paulatinamente separando os camponeses da terra e concentrando as riquezas monetárias e os meios de produção nas mãos da burguesia. Diferentemente dessa linearidade, nosso estudo tentará revelar no presente ciclos da reprodução social da agricultura que relegam segmentos sociais a um processo de estigmatização historicamente construído, e que são ressignificados diante de uma experiência de expropriações, resistência e reocupações.

A reconstrução social da agricultura é contemplada aqui como um choque, uma tensão permanente entre agentes sociais em conflito para a ordenação de um dado território. E, ao mesmo tempo, os movimentos sociais enfrentam cenários de recuos e avanços para a democratização do acesso à terra e para o reconhecimento de diferentes saberes. A própria combinação de saberes por parte dos trabalhadores rurais (re)constrói "relações com a natureza que retomam processos de gestão", questionam os processos homogeneizadores da produção, assumem posições críticas à destruição dos ecossistemas e aos contínuos processos de exclusão social (Brandenburg, 2005). 


\section{ANTECEDENTES SOCIO-HISTÓRICOS}

Tratando-se de uma descrição que contempla as dinâmicas sociais em processo, a perspectiva do presente sobre o passado faz-se elucidativa, quando percebemos as práticas de dominação e, principalmente, quando conseguimos revelar determinados resquícios da nossa colonização, relevantes para explicar nosso momento atual. Há histórias do Vale do São João que precisam ser apresentadas de forma que seja possível identificar os desdobramentos que vem a formar o que Novicki (1994) classifica de "politização da questão agrária" no estado do Rio de Janeiro (pré-1964). Eis um mosaico de conflitos que tem origem no próprio processo de colonização, como primeira reprodução social da agricultura que se relaciona à concentração de terras e à crise ambiental contemporânea.

De uma perspectiva territorial, torna-se elucidativa a reflexão de Haersbaert, quando relaciona o processo de desterritorialização política com o aparecimento do Estado. Isso acontece, principalmente, quando o Estado se torna responsável ou agente da destruição de economias originárias, suas redes de sociabilidade e suas relações com o meio ambiente. Assim, a territorialidade original foi praticamente destruída, o que possibilitou uma recodificação ou "reterritorialização complexa, que, ao mesmo tempo em que destrói as territorialidades prévias, reincorpora-as e produz uma nova forma territorial de organização social" (Haesbaert, 2004: 197) no capitalismo.

Desterritorialização que, num primeiro momento histórico, podemos identificar como colonização. O Estado português, segundo Lamego (1945), “criminalizou" os índios porque, de acordo com uma imagem/ideologia de dominação, "não dão exercício as terras que possuem; [...] que abrangem as margens daquele rio e de outros, sem a menor cultura, como se vê no de São João" (Lamego, 1945: 71). Eis que os primeiros registros das atividades econômicas datam do século XVII, através da cultura da cana-de-açúcar e do extrativismo.

Antes, no século XVI, há uma descrição do comércio na região, pertencente à área de abrangência da feitoria de Cabo Frio, naquele momento sob arrendamento de Fernão de Noronha. A passagem da nau Bretoa, ao mesmo tempo que significava um instrumento de vigilância e defesa das novas terras conquistadas pela coroa portuguesa, organizava de forma rudimentar o comércio colonial. Há descrições afirmando que o pau-brasil de Cabo-Frio era superior em qualidade ao das feitorias do Norte. No dia 26 de maio de 1511 a "Bretoa" já embarca mercadorias a partir dessa feitoria: "Levou cinco mil toros de pau-brasil, vinte e dois tuins, dezesseis saguis, dezesseis gatos, quinze papagaios, três macacos, 
[...] quarenta escravos, na maioria mulheres." (Lamego, 1946: 134). Mas a feitoria lusitana teve uma vida efêmera.

Há indícios, apontados por Lamego (1946), de que duas nações indígenas, os tamoios e os goitacás, habitaram essas terras que ora estudamos. Enquanto os tamoios concentravam-se nas lagoas e enseadas, os goitacás eram donos absolutos das planícies e das restingas. Apesar do conflito contra os portugueses, as duas etnias lutavam isoladamente (contra os invasores e entre si). Para Bezerra de Menezes (Lamego, 1945: 128), embora goitacás - mais presentes no que hoje são os municípios de Silva Jardim e Casimiro de Abreu - signifiquem, na tradução vulgar, "índios corredores", segundo a tradução do autor citado, a etimologia correta vem de guaita-guaçu, de onde derivaram os termos guaitaguás e guaitacás, que significa "nadadores grandes".

Os colonizadores europeus (portugueses e franceses) se depararam com uma etnia resistente ao domínio estrangeiro: "Não há como dominá-los. Os trabucos falham. Falha a varíola disseminada. Falha toda tentativa de entendimento" (Lamego, 1945: 69). As características físicas do meio ambiente, a umidade e as chuvas dificultavam o uso de armas, as características ecológicas (doenças) eram mais severas contra os europeus, e as doenças dos europeus eram menos devastadoras nessa região. Cria-se, então, um impasse no processo de colonização, pois, confirmando a tese de Alfred Crosby (2011), o componente biológico/ecológico europeu pode ser descrito como um dos instrumentos de dominação mais eficazes. Mas, nesse território, o componente ecológico local (chuvas, febre amarela e pântanos etc.) foi superior ao estrangeiro, sendo que o êxito do imperialismo colonial teve uma limitação nessa conjuntura histórica e ambiental.

A fundação de Cabo Frio tornou-se estratégica para a conquista dos goitacás e, também, para a criação dos primeiros latifúndios, controlados por jesuítas 5 . A própria organização das futuras cidades do Vale do São João se origina de aldeamentos organizados por jesuítas: Aldeia de São Pedro (Cabo Frio); Aldeia Sacra Família de Ipuca (Casimiro de Abreu); Aldeia Nossa Senhora das Neves (Macaé).

Eis uma descrição sintética das primeiras formas de expropriação das terras do Vale. Ao longo dos séculos XVII e XVIII, os jesuítas e alguns colonos se estabeleceram na margem esquerda da foz do rio São João. Ali ergueram uma igreja,

\footnotetext{
${ }^{5}$ A influência dos núcleos jesuítas é destacada por Lamego (1946), segundo o qual são organizações de ensino e de mobilização que podem ser recordados no Colégio que existia no morro do Castelo (Rio de Janeiro), três capelas jesuítas em Niterói, convento de São Pedro em Cabo Frio, a própria fazenda Campos Novos, igreja de Sant'Ana em Macaé, entre outros. Na região em estudo, há que se destacar a descrição da construção de um convento em São Pedro da Aldeia em 1738 pelos jesuítas.
} 
construída sob invocação de São João Batista. Esse fato representa um indício sobre a origem do próprio nome do rio, pois São João é o santo que batizou Jesus Cristo, no rio Jordão. Neste artigo, o rio São João pode ser lido em temporalidades, num campo de disputa em particular: o Vale do São João. O processo de exploração dos recursos naturais do Vale intensifica-se com a navegabilidade do rio ${ }^{6}$.

A fundação de uma fazenda pelos jesuítas foi a porta de entrada para desbravar a bacia hidrográfica do rio São João. As primeiras experiências produtivas envolveram a cultura da cana-de-açúcar, e em seguida com o ciclo econômico cafeeiro (mas esse de curta duração). O abandono das grandes propriedades, a ocupação das terras por posseiros e a extração de madeira nobre e animais são símbolos do Vale do São João.

A passagem do século XVIII para o século XIX representou um novo momento de interiorização, que é simbolicamente marcado pela construção da estrada de ferro pelo território do Vale do São João. Um estímulo para a devastação da Mata Atlântica nessa região. Esse processo de "conquistas" e colonização do interior do estado do Rio de Janeiro representou, para Dean (1996), um cerco contra a Mata Atlântica, onde o processo de expropriação privada estava em sua fase final, já no início do século $\mathrm{XX}^{7}$.

Já na primeira metade do século $\mathrm{XX}$, os produtos mais valorizados no território são não agrícolas, possivelmente uma das causas para a concentração de grandes propriedades. Grandes proprietários e empresas passaram a comprar terras com reservas de mata, cuja exploração visava principalmente à produção de energia com lenha e carvão (Geiger \& Mesquita, 1956). A construção da ferrovia, o desmatamento para abertura de pastos, a argila para a produção de cerâmica e a areia para construção são elementos que se conectam numa série de ações causadoras de enorme impacto ambiental no território do Vale do São João.

\footnotetext{
6 "Ao estudarmos a região dos pantanais, assinalamos as paisagens desoladoras marginais ao rio São-João, onde os morros se destacam sobre um dilúvio generalizado por ilimitadas extensões encharcadiças; isto não impede, porém, que os desbravadores por ali entrassem desde tempos remotíssimos. É que duas condições geográficas essenciais à vinda do imigrante ali se encontram: o porto, que é o melhor de todas essas pequenas embocaduras de rios da Baixada, propício à navegação de modesto calado, e a profundidade do próprio São-João por dezenas de quilômetros, permitindo a penetração para os fundos montanhosos da bacia. [...] As madeiras de lei, em toras ou serradas, desceram das matas do sertão trazidas pelos caminhos d'água. Por tais vias de acesso torna-se possível o escoamento de produtos da lavoura..." (Lamego, 1946: 166)

7“A civilização urbano-industrial havia triunfado - seus tentáculos se espalharam por toda parte, sua ânsia por combustível, madeira e outros recursos florestais se estendia por toda a Mata Atlântica. A floresta, ainda que reduzida a faixas cada vez menores, aumentava de valor, à medida que essas demandas se tornavam mais insistentes. Os críticos efetivos ao desperdício e aos desmandos reduziram-se em grande parte à elite tecnocrática e científica.” (Dean, 1996: 278-279)
} 
Eis que no início do século XX já era possível identificar os efeitos desses primeiros impactos ambientais. Como resultado da devastação há uma proliferação de doenças tropicais, como noticiavam os jornais: "O abandono do vale [do São João] pelos grandes proprietários rurais aconteceu depois de uma epidemia de febre amarela, que o atingiu nos anos 30" ("Região abandonada", 1973). Há um processo planejado e flagrante no sentido de atribuir a suposta decadência agrícola a motivos "naturais".

Já na segunda metade do século XX encontramos indícios de uma tentativa de retomar a vocação agrícola do território do Vale do São João ${ }^{8}$. Em nome de um conceito de modernização, relacionada ao desenvolvimento urbano e ao higienismo, debatia-se sobre uma pretensa falta de vocação rural a ser contornada via investimentos e obras públicas. Identificamos ciclos econômicos na agricultura fluminense, desde a cana-de-açúcar, o café, a fruticultura, e, em todo momento, a devastação da Mata Atlântica. A mudança da correlação de forças entre o campo e a cidade passou a ser o traço fundamental no desenvolvimento econômico da região.

De modo genérico poderíamos dizer que há uma resposta consensual aos desafios para o desenvolvimento brasileiro ao interpretar a agricultura ou como "entrave" ou como uma atividade necessariamente "funcional" para o crescimento econômico, sempre subordinado à perspectiva da industrialização (Gonçalves Neto, 1997). A Comissão Econômica para América Latina (CEPAL), entre os anos 1950 e 1960, identifica a reforma agrária como elemento fundamental para a industrialização e superação do subdesenvolvimento, vendo o campo como espaço para o avanço tecnológico e o aumento da produtividade. A crítica à arcaica estrutura agrária brasileira, centrada no latifúndio, foi identificada como um obstáculo para responder à demanda urbano/industrial. Com a produção calcada no monopólio da propriedade da terra, em mãos dos latifundiários, e nas relações de produção antiquadas vigentes, a reforma agrária e a modernização da agricultura apareciam como respostas plausíveis para os principais teóricos da época.

Até a metade do século XX, há registros de pelo menos quatro conflitos fundiários que envolvem violências contra posseiros do Vale do São João, ocorridos nas fazendas de Palmeiras, Córrego Feio, São Mateus e Cambucaes. Os registros sobre o limite das propriedades não estavam claros, e a presença de posseiros era uma das características do Vale.

\footnotetext{
${ }^{8}$ Para Sônia Mendonça (1997), o ideário da "vocação agrícola" brasileira foi elaborado no início do século XX, que permitiu vislumbrar a união entre a indústria e a agricultura, ou seja, a subordinação do campo à cidade.
} 
Segundo dados coletados e sistematizados a partir de pesquisas realizadas pela Secretaria de Assuntos Fundiários e Assentamentos Humanos do governo do Estado do Rio de Janeiro (1991) e pelo Núcleo de Pesquisa, Documentação e Referência sobre Movimentos Sociais e Políticas Públicas no Campo (NMSPP) do CPDA/UFRRJ, o abandono da terra, em decorrência das epidemias ou da decadência das culturas comerciais promoveu uma nova forma de apropriação e especulação das terras. Esse processo colocou em conflitos fazendeiros, posseiros e grileiros ${ }^{9}$, a exemplo dos relatos coletados sobre a fazenda Córrego Feio ${ }^{10}$.

O deslocamento populacional apresenta-se como característica de um processo iniciado na década de 1950, que ganha proporções maiores nas décadas seguintes. Depoimentos coletados sobre a Fazenda Palmeiras (NMSPP CPDA/UFRRJ) dão a dimensão do conflito no município de Casimiro de Abreu (mas que hoje faz parte do município de Rio das Ostras, que se emancipou em 1992). Trata-se de um exemplo sobre a evolução de um conflito entre posseiros e fazendeiros, pois a antiga área da fazenda transformou-se, hoje, em um bairro, em um loteamento urbano.

Na década de 1950, mesmo em amplo processo de urbanização, é possível identificar diferentes formas de resistência dos trabalhadores para o acesso a terras. Em 1965, promulgou-se decreto federal, visando à criação de uma zona prioritária de emergência para fins de reforma agrária, na região fisiográfica definida pelo IBGE como Baixada do rio São João (Decreto no 57.081 , de 15/10/65). O objetivo inicial era permitir a implantação de colônias agrícolas, porém rapidamente os interesses dos especuladores se sobrepõem, e uma série de processos de grilagem e concentração de terras podem ser identificados. $\mathrm{O}$ desdobramento desses interesses se caracterizou não só por uma intensa onda de conflitos, como também pela gradativa desagriculturalização fluminense.

\footnotetext{
9 "As obras de infraestrutura costumam atrair os especuladores de terras que, munidos de falsos títulos de propriedade, tratam de expulsar os posseiros de suas áreas de cultivo. Segundo os técnicos agrícolas que nos anos 60 atuaram nos órgãos da política agrária do Governo, existe, no Estado do Rio de Janeiro, uma 'indústria do grilo', com a falsificação de escrituras cartoriais. Na região conhecida como Baixada Fluminense, situada entre as encostas da Serra do Mar e o Oceano, muitos títulos de propriedade ainda são considerados duvidosos." (O'Dwyer, 1982: 14)

10 "José Pureza da Silva (1982) menciona que, já por volta de 1955, ocorreu um despejo em Capivari, decretado [...] Os posseiros, em reação a esta primeira situação de expropriação, organizaram uma grande mobilização e acamparam no Campo de São Bento, em Niterói, por mais de um mês. A saída encontrada pelo governo para sanar a situação foi a alocação das famílias em Córrego Feio, município de Casemiro de Abreu. Mas muitos lavradores recusaram a solução e retornaram a Xerém." (NMSPP, 2015: 272)
} 


\section{ModerniZAÇÃO E "DESAGRICULTURALIZAÇÃO" DO VALE DO SÃO JOÃO}

A reconstrução social da agricultura será relida nessa parte do artigo como um processo de cima para baixo, sintetizada em conflitos fundiários e socioambientais. Para tal, faz-se necessário um recorte temporal, que vislumbre de forma resumida os principais marcos para a "modernização" do Vale do São João. Seguimos aqui a classificação de Novicki (1994) em três fases: politização da questão agrária (pré-1964); despolitização autoritária (1964-1978); e, repolitização (pós-1979).

Nesse sentido, temos como marco histórico, primeiramente, a década de 1950, com o início dos conflitos entre posseiros, grileiros e fazendeiros. Em um segundo momento, esses mesmos conflitos, que emergem ao longo das décadas de 1950 e 1960, são recontextualizados no Golpe Militar de 1964, momento em que a repressão às lutas em suas diversas formas de violência, são institucionalmente dirigidas pelo Estado contra os segmentos sociais que reivindicam as terras. Por fim, o renascimento dos movimentos sociais no período de redemocratização, décadas de 1980 e 1990 - momento de surgimento do acampamento Sebastião Lan II.

Desde o início do século $\mathrm{XX}$, há registros das seguintes atividades nos municípios de Casimiro de Abreu e Silva Jardim: café, cana, arroz, extração de madeira, lenha, banana e uma variedade de lavouras de curta duração. No início dos anos 1970, os jornais anunciavam uma retomada da produção agropecuária, em sintonia com o projeto de modernização.

As manchetes e matérias do Jornal do Brasil sobre o Vale do São João mostravam a abertura de uma nova fronteira agrícola: "Comissão se reúne a fim de fazer do vale do São João um cinturão-verde do rio" (Convênio com DNOS..., 1971); "Produção no vale S. João é estimulada" (1973); "Citricultura tem boas perspectivas de se desenvolver" (1973); "Vale do São João tem só culturas típicas e será área de hortigranjeiros" (1973); "Região abandonada abastecerá o Rio" (1973); "Novo Estado do Rio poderá tirar melhor proveito de uma agricultura racional" (1974).

\footnotetext{
11 "Refere-se ao processo de esvaziamento da atividade agrícola, especificamente localizado no Estado do Rio de Janeiro, a partir de políticas públicas geradas segundo concepções de gabinete (planejamento de cima para baixo), por sua vez, fortemente influenciadas por interesses especulativos atrelados ao capital imobiliário, ou políticos [...] Manifesta-se no processo de marginalização estratégica do setor da agricultura familiar, vinculada à produção de subsistência [...] em favor do suporte à monocultura [...]" (Ribeiro, 2005: 158).
} 
Nota-se que a presença do Estado foi tida como indispensável para o estímulo do desenvolvimento e, por conseguinte, da industrialização, assim podemos contextualizar o I Plano Nacional de Desenvolvimento (I PND), de 1972 a 1974, e o II PND, de 1975 a 1979. Procurava-se desenvolver um setor industrial voltado para a produção de máquinas e equipamentos agrícolas, defensivos, adubos e insumos. Nesse sentido, região do Vale do São João na década de 1970 foi então alvo de ações governamentais para a implantação de projetos agropecuários, da monocultura de arroz, com a construção da Barragem de Juturnaíba, além da construção de canais para drenagem da região, com o uso de insumos químicos, agrotóxicos e irrigação (Binzstock, 1998) ${ }^{12}$.

Ao mesmo tempo em que cumpriam seus compromissos com a "modernização" e com a "produção", as grandes obras tinham como ênfase contemplar projetos de mediação com as oligarquias locais para assegurar a "estabilidade" política. Estabilidade para uma redefinição da ocupação do vale, como aponta o geógrafo Jacob Binstock (1998), que desenvolveu uma pesquisa na região num momento de transformação de um território camponês em um território para os latifúndios. Ou seja, podemos visualizar um ciclo de concentração fundiária e contemplar essa transição, de um território ocupado por uma pequena agricultura que foi expulsa para uma agricultura "moderna"13.

$\mathrm{Na}$ imagem (Figura 1), publicada no Jornal do Brasil, o Governo do Estado do Rio de Janeiro (1970) anunciava um novo rural, mais moderno. Esse projeto de modernidade pode ser analisado à luz da explicação da própria propaganda veiculada:

[...] queremos acabar com o homem da roça doente. Com o homem da roça sem auxílio, sem apoio técnico, sem ajuda financeira para plantar e colher cada vez mais e melhor. Queremos acabar com aquele homem da roça sem escola para seus filhos, sem mercado para seus produtos. Queremos acabar com o homem da roça que é obrigado a deixar sua lavoura para tentar a vida na cidade grande, onde geralmente não se adapta e costuma se transformar em favelado. [...] O aproveitamento do Vale do Rio São João, o Plano de

\footnotetext{
12 "No caso do São João, constituiu-se num 'pacote' de obras civis, executadas pelas maiores empreiteiras do país, sob supervisão do Departamento Nacional de Obras e Saneamento, DNOS, que retificou os leitos dos rios São João, Macaé e afluentes, abriu "profundos" canais de drenagem, contrariando a lógica do desenvolvimento agrícola, e construiu a barragem de Juturnaíba, em Silva Jardim. Com respeito aos impactos proporcionados pelas obras de infraestrutura promovidas pelo 'milagre' brasileiro, a região beneficiou-se da abertura da BR-101, que "cortou' o núcleo urbano de Casimiro de Abreu e da construção da ponte Rio-Niterói." (Binsztok, 1998: 327-328)

13 "Dentro do vale do São João, o homem nativo, que resistiu às epidemias e não emigrou, pouco difere das antigas populações indígenas. A comunicação entre os elementos de um habitat disperso e linear é feita principalmente por meio de pequenas embarcações, numa região onde dominam os pântanos e os remanescentes de antigas reservas florestais." ("Vale do São João tem só culturas típicas e será área de hortigranjeiros", 1973)
} 
Mecanização da Lavoura, [...] são outras frentes de trabalho que estamos atacando. No Estado do Rio, no lugar do velho e esquecido homem da roça, está surgindo um novo homem do campo. (Governo do Estado do Rio de Janeiro, 1970)

Figura 1. Propaganda do Governo do Estado do Rio de Janeiro, PUBLICADO NO JORNAL DO BRASIL

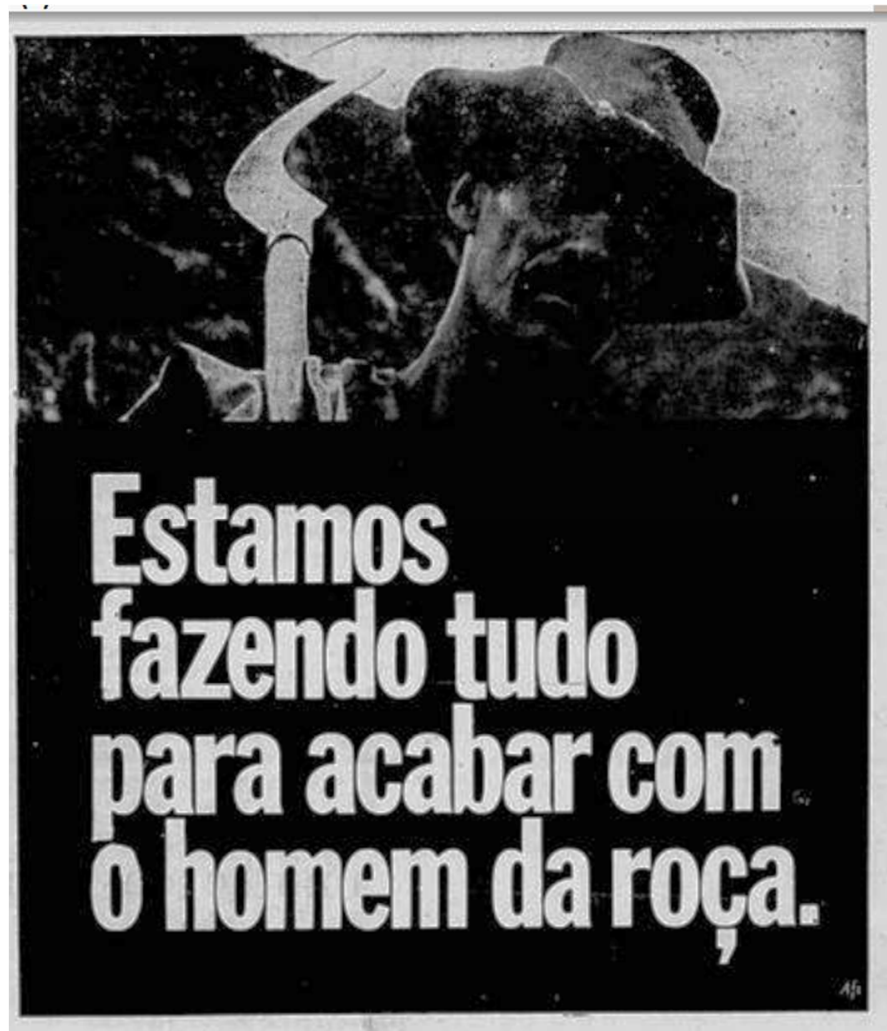

Fonte: Governo do Estado do Rio de Janeiro, 1970.

A associação do "homem da roça" à "doença" traz, em si, todo o debate em torno da noção e do conceito de "desenvolvimento" enquanto uma associação de um tipo de "rural" e do "agrário" como "atraso social" ou como "entrave ao desenvolvimento", e as relações de dominação do meio rural como relações de opressão do passado ("resquício do feudalismo" ou "semi-servidão"). A melhoria das condições de vida no campo e a necessidade de criação de um ambiente propício ao desenvolvimento de uma economia de mercado recolocam o tema do progresso, da urbanização e da reforma agrária como condições para superação desse "atraso econômico e social", de acordo as teses compartilhadas na época. 
Assim, torna-se possível identificar e melhor compreender o investimento realizado pelo extinto Departamento Nacional de Obras de Saneamento (DNOS), órgão do Governo Federal, no Vale do São João. Ao promover um processo de "modernização conservadora" (Graziano da Silva, 1982), o Vale se moderniza, mas também mantêm antagonismos e assimetrias sociais. A aliança com latifundiários da região, significava, ao mesmo tempo, a ampliação da devastação florestal - movimento que caracteriza uma modernização seletiva, com contornos regionais.

Dessa forma, em paralelo às manchetes e matérias, encontram-se reportados indicadores e indícios do impacto ambiental produzido: "Os madeireiros não poupam as regiões dos mananciais, desmatando-as e reduzindo, pela erosão provocada, o volume de água de alguns rios.” (Desmatamento, 1971); “Apreensão de 428 sacos de carvão, provenientes do rio São João" (Desmatamento, 1971); "Homem tenta reparar danos que causa à natureza" (1972).

Sobre as representações de grandes proprietários rurais, percebe-se a permanência de um modelo patrimonialista de gestão dos bens públicos e uma articulação com as classes dominantes, concomitantes a princípios de um Estado Moderno, pretensamente promotor de eficiência empresarial (Seva, 2008). Podese deduzir que o processo de modernização do Vale do São João foi orquestrado de forma a expulsar posseiros e povos tradicionais; estimular o desenvolvimento agropecuário $^{14}$; criar um limite ou compensação ambiental para responder à comunidade internacional e colher investimentos; além de abrir espaço para que o capital especulativo investisse na Região dos Lagos, numa associação entre setores da elite, urbanos, agrários e financeiros.

O problema das enchentes sazonais e a composição de um terreno pantanoso foi alvo de grandes obras com recursos públicos. Isso permitiu uma maior abrangência territorial das grandes propriedades. Esse retrato é sintetizado na entrevista, realizada pela UFF em 2002, que consta no acervo do Observatório Fundiário Fluminense:

- Como é que o Senhor instalou essa fazenda?

- Você sabe que alguma coisa que quiser você tem que fazer. Tive que fazer tudo.

- Era mata?

- Era mato, mata, e pântano, que ali é alagado, o que tem hoje em dia foi conseguido por nós, naquele período que existia o DNOS, que tinha verba adoidado aí, então conseguimos essa dragagem que existia ainda. Se existe aquela dragagem lá foi trabalhando na

14 “O plano do Governo objetiva, ainda, o estímulo, no Vale do São João, de maiores concentrações de fazendas de gado de corte. Na parte agrícola, a ideia é racionalizar a produção de hortaliças [...]" ("Estado tem verbas para recuperação do Vale do São João", 1973) 
região, na nossa fazenda ali, passava a semana toda e trabalhando, trabalhando e abrindo e fazendo pasto e requisitando aqui... as capoeiras vagabundas nós tirávamos fora e depois entramos com pedido de licença pra desmatar uma parte lá que... e deixamos a área de reserva que existe lá até hoje, né. Nessa época o Ibama nos fez a concessão, fez a outros grupos também né, outras pessoas. Então temos uma fazenda que comporta mil e tantos animais, né? Para época só tinha pasto pra seis bois de lá pra cá..."15

Como justificativa, as áreas alagadas - como os brejos, característicos da região - foram consideradas locais insalubres, focos de malária, e, portanto, alvos do projeto de saneamento do DNOS (Geiger \& Mesquita, 1956). As mudanças têm efeito até hoje. A construção de canais de escoamento e drenagem da água vinda do rio São João favoreceu a implantação de projetos agropecuários, que associavam monoculturas de arroz, cana e gado.

Em lugar de uma lagoa ${ }^{16}$, surge a barragem de Juturnaíba, cujo reservatório foi formado e inundado entre os anos de 1982 e 1984. Obra, que, por si só, foi responsável por alguns impactos irreversíveis - a mata ciliar do rio São João foi quase extinta. Segundo a professora de geografia da UFF, Sandra Cunha (1995), a realização dessas obras de engenharia rompeu com o equilíbrio da região e provocou modificações na flora, na fauna e no comportamento do próprio rio. Essa barragem, que redefiniu os limites da Lagoa de Juturnaíba, estaria dentro de um contexto maior de especulação imobiliária, que teria como objetivo principal a captação e o armazenamento de águas doces, visando sustentar o processo de urbanização e o atendimento de uma agricultura em larga escala. A construção da barragem objetivava garantir o abastecimento das cidades em desenvolvimento próximas, fornecendo também suporte ao turismo na região dos Lagos.

Nesse mesmo contexto, houve a implementação da Reserva Biológica de Poço das Antas, em 1974, que envolveu questões importantes e problemáticas relativas à concentração de terras, modos de exploração do solo e dos recursos hídricos. A justificativa para a criação da reserva foi a preservação do mico-leãodourado (leontotithecus rosalia rosalia), espécie com risco de extinção, em consonância com a pauta internacional trazida pelo movimento ambientalista, em torno dos riscos ecológicos advindos da intensa degradação da Mata Atlântica.

Na pesquisa realizada em publicações do Jornal do Brasil com notícias sobre o Vale do São João, no contexto da criação da Reserva Biológica

\footnotetext{
${ }^{15}$ Presidente do sindicato patronal rural de Silva Jardim, GT ECOSOCIAL, junho de 2002.

${ }^{16}$ Descrição de Lamego, na década de 1940, da lagoa de Juturnaíba: "Em toda essa região abandonada em que o espírito acabrunha com tamanha desolação, é essa a única nota que nos maravilha pelo inesperado com que nos assalta: a lagoa de Juturnaíba. A lendária 'Nhetoronia-aba' ou 'malassombrado', outrora tão temido por seus horrendos ururaus, e que hoje nos enleva, fascinante e soberba com suas limpas águas entre margens colinosas [...]" (Lamego, 1946: 63)
} 
(envolvendo um corte temporal de 1970 até 1975), foi possível encontrar 46 matérias relativas ao assunto. A ênfase das reportagens girava em torno de três grandes variações temáticas. Destacamos o primeiro tema em prol do desenvolvimento rural, que contemplava investimentos, obras do DNOS, construção de canais e estradas para escoar a produção (28 casos, ou 61\%). Em segundo lugar, vinham as reportagens contendo denúncias relativas a desmatamento, caça, ações do IBDF no Vale e outros conteúdos de cunho preservacionista (16 casos, ou $35 \%$ ). Por último, apenas duas matérias denunciavam violência na região e a concentração fundiária (4\%), curioso considerando a grande quantidade de famílias expulsas de suas terras.

O decreto que cria a Reserva Biológica de Poço das Antas é de 11 de março de 1974. Em 14 de julho do mesmo ano, publica-se matéria que apresenta uma conciliação das perspectivas desenvolvimentistas e preservacionistas bem curiosa. Sob o título "Vale do São João tem prioridade para o saneamento", descrevem-se as ações realizadas, como a dragagem de 1.500 quilômetros de rios e canais e a construção da barragem de Juturnaíba, como se essas ações fossem, também, positivas para o equilíbrio ambiental, conservando os mananciais de água doce, ao canalizá-los.

Apesar de a criação da unidade de conservação ter ocorrido em 1974, os debates começaram com a Fundação Brasileira para a Conservação da Natureza, em 1968. Indicava-se, então, a importância dos primatas para a pesquisa biomédica e para a indústria farmacêutica (Universidade Federal Fluminense, 2007). Matérias do Jornal do Brasil já anunciavam a desapropriação de áreas para a construção da Reserva desde $1970^{17}$. Mesmo com a criação da unidade de conservação, a devastação continuava. Relatos de caçadores presos, desmatamento e produção de carvão permanecem, mesmo após 1974. Em 7 de março de 1975, o Jornal do Brasil denunciava: "Nem Reserva detém desmatamento".

Nos anos que se seguiram, compreendidos entre o início das pesquisas e a criação efetiva da Reserva, o debate se acirra. Órgãos do Governo brasileiro, a exemplo do Departamento Nacional de Parques, vinculado ao Instituto

${ }^{17}$ O Jornal do Brasil, no dia 6 de setembro de 1970, continha uma matéria com o título "Estado do Rio desapropria área para manter suas florestas" (1970). A reportagem anunciava os estudos de área do município de Silva Jardim para desenvolvimento de uma reserva biológica: "Trata-se de uma espécie rara de símio, que em todo o mundo só é encontrado dentro do vale do rio São João, cuja captura ou morte pode acarretar ao caçador menos avisado prisão de dois a cinco anos e multa de 100 salários mínimos regionais. Esta proteção à espécie foi prevista em decreto-lei do Governo federal, editado pelo ex-Presidente Castelo Branco. Apesar do rigor da lei, a espécie continua em perigo de extinção" (p.7). A matéria enfatizava que restavam apenas 600 micos em toda área. 
Brasileiro de Desenvolvimento Florestal (IBDF), ou mesmo grupos internacionais como a World Wide Fund for Nature (WWF), destacavam a urgência da criação de uma reserva, capaz de propiciar a não extinção do mico-leão-dourado.

Concomitante à desterritorialização, Haesbaert (2004) identifica outra forma de reterritorialização, denominada "extraterritorialidade", que diz respeito a uma rede, para além das fronteiras nacionais, possível apenas com a integração dos mercados, realizada via capital financeiro. A eleição do mico-leão-dourado como símbolo da preservação não significou exatamente uma forma de expropriação, mas sim uma extraterritorialidade, um processo que integra o território numa rede mundial preservacionista, com investimentos para além do controle e administração do Estado nacional ou da população da região impactada. No mesmo sentido podemos contemplar a temática do mico-leão como uma demanda da cidade para o campo, ou seja, um novo indício da sobreposição dos interesses urbanos sobre os interesses rurais ${ }^{18}$.

O projeto de modernização do Vale do São João caracteriza-se como campo privilegiado de estudos, pois seu desenvolvimento, ao mesmo tempo em que representou uma expansão da fronteira agrícola fluminense, na década de 70, também promoveu a rearticulação das elites rurais com o capital especulativo imobiliário, mediante a expropriação de pequenos posseiros da região e a combinação de grandes obras/devastação ambiental, com a construção de ilhas de preservação ambiental. $\mathrm{O}$ "negócio da terra passou a interessar não somente àqueles latifundiários, mas também a "banqueiros a setores de classe média prósperos, beneficiários do 'milagre econômico', que começaram a adquirir terra para especular" (Palmeira, 1994: 50).

Conforme matérias publicadas na década de 1970, houve uma intenção de estimular uma pretensa "racionalização" da agricultura. Essa "racionalização" também simbolizou uma nova integração com o mercado, como podemos observar nas seguintes reportagens da época, sobre: "o aproveitamento agrícola e industrial dos vales úmidos do país [que] pretende transformar a região em celeiro de produtos hortifrutigranjeiros" ("E. do Rio faz projeto integrado", 1973); ou, um "grupo de São Paulo entrou em entendimentos com o prefeito de Casimiro de Abreu [...] visando à instalação de uma fábrica de industrialização de palmito" ("Palmito será aproveitado em Casimiro", 1973), etc. Ou seja, a década de 1970

\footnotetext{
18 “A maior divisão do trabalho material e mental é a separação da cidade e do campo. [...] A cidade já é, na realidade, a concentração da população, de instrumentos de produção, de capital, de prazeres, de necessidades, enquanto o campo representa, justamente, o oposto, seu isolamento e separação.” (Marx, 1977: 118).
} 
deve ser estudada tendo como referência num processo novo na história brasileira, citado por Delgado (2005), que foi a união do capital financeiro com a renda provinda da terra. Como nova oportunidade de ampliação dos investimentos no Brasil, através de frentes de expansão, o uso da terra sugere um processo de ocupação, e acesso à renda da terra e, por extensão, da natureza.

As lutas de resistência camponesa contra as formas de proletarização e/ou a expulsão de suas terras fizeram com que os militares identificassem nessas lutas questionamentos contra o direito de propriedade instituído, diz Martins (1981). Há, também, algumas evidências que confirmam formas de luta contra esse processo, desencadeadas por pequenos agricultores da região estudada.

Num primeiro momento obtêm-se a coleta de dados a partir dos jornais da época, que relatam três episódios que merecem destaque, seja do ponto de vista da existência de comunidades tradicionais (quilombos), seja pelos "crimes" denunciados contra fazendeiros, seja, até mesmo, pela constatação do elevado grau de concentração de terras: (1) "Um caboclo seminu, possivelmente descendente de algum quilombo do tempo da escravidão, foi visto [...] às margens do rio São João, onde existe uma reserva florestal." (IBDF acha ser armado com flecha, 1973); (2) "É muito grave o clima de tensão na Zona Rural [...] onde quadrilhas organizadas estão atuando em fazendas e roubando gado" (Informe RJ, 1973); (3) "o município de Casimiro de Abreu apresenta uma distribuição de terras desequilibrada [...] mostra o quadro de uma agricultura ainda calcada no latifúndio e no minifúndio." (Técnicos indicam no Estado do Rio problemas de distribuição de terra, 1973).

A partir de levantamentos e estudos sobre os conflitos fundiários no Vale do São João durante o período militar, pode-se destacar o conflito Vila Nova (processo arquivado em 1989); e o caso da fazenda Brasileira ${ }^{19}$, em que há registros de violências a partir da década de 1970, envolvendo 46 famílias (O'Dwyer, 1982). Outros relatos de violência, sistematizados pelo NMSPP (CPDA/UFRRJ), demonstram como o processo de expansão da fronteira agrícola fluminense envolveu a expropriação de posseiros do Vale do São João. Na Fazenda Coruja, no município de Casimiro de Abreu, numa área desapropriada pelo Governo do Estado, 50 famílias de posseiros começaram a ser expulsas na década de 1970. Como a desapropriação não foi efetivada, os posseiros denunciavam ameaças, intimidações e perseguições pelos pretensos proprietários das terras. Em Silva Jardim, há outro caso, com 47 famílias de posseiros foram alvo de violências semelhantes.

\footnotetext{
${ }^{19}$ Essa área, assim como a fazenda Palmeiras, transformou-se em bairro/loteamento urbano do município.
} 
O processo de desagriculturalização associou-se ao aumento do valor da terra e a consequente ampliação da devastação ambiental para ampliação da área útil para fins especulativos. Em entrevista com um ex-arrendatário, proveniente do Sul do país (que chegou nos anos 1980 para a plantação de arroz), há uma conversa reproduzida por ele com um antigo fazendeiro cuja terra fora por ele arrendada, o que demonstra a decadência produtiva dos latifúndios da região:

- O senhor me diz o que o senhor tem? O que o senhor tem além da nossa plantação? O senhor tem um monte de pasto vazio, cheio de capoeira, que nem pasto é. Isso pra mim é capoeira, não é pasto. Seus bois vive bichado. Então o que é que o senhor produz nessa fazenda? Nada. Falei assim pra ele. Ele desmatava tudo pra fazer carvão, se você correr aí pra dentro vai encontrar ainda os fornos de carvão, tinha mais de vinte (Entrevistado A em 2017)

A presença dos antigos e novos fazendeiros do Vale do São João tornouse hegemônica, apesar de identificarmos contradições na sua composição. Devemos citar a presença de novos proprietários que procuraram recuperar o meio ambiente degradado, recompor as Reservas Legais e realizar práticas agroecológicas, estimulando o turismo. De qualquer forma há evidências de que setores subalternizados do Vale do São João, agricultores familiares e comunidades tradicionais, foram forçados a saírem de suas terras com as obras de infraestruturas e por ações para expropriação de suas terras. Obras e projetos de modernização da agricultura acabaram se tornando um repositório de violências, seja pela ampliação de um novo projeto de agricultura ("racionalizada e intensiva") ou pela especulação imobiliária - que ampliava suas fronteiras.

O conceito de desagriculturalização aparece como uma característica ou peculiaridade do processo de acumulação primitiva do capital fluminense, que tem como face visível a monocultura e a reconstrução social da agricultura como imoblização do capital em terras (Moreira, 1995), ou seja, pastos vazios e aparente improdutividade. Portanto, uma idiossincrasia da modernização conservadora no Rio de Janeiro, que expropriou e concentrou terras, é a própria desagriculturalização - um movimento de apropriação da renda da terra que vem a se constituir num investimento especulativo, uma reserva de valor e novas formas de apropriação de elementos da natureza, em vias de mercantilização. 


\section{5. “RERRURALIZAÇÃO” ${ }^{20}$ E A RECONSTRUÇÃO SOCIAL DOS “PÉS DE SONHO”}

No processo de modernização conservadora do Vale do São João houve um acúmulo de conflitos socioambientais não resolvidos: escravidão, extrativismo, derrubada da mata nativa, queimadas, produção com agrotóxicos. Eis que os exemplos e os tipos idolatrados de um moderno empresariado rural transformar-se-iam em donos de pastos, donos de lotes, "sócios" da Prefeitura, sócios de hotéis, donos de uma Reserva Privada do Patrimônio Natural (RPPN), gerentes de uma ONG, gerentes de bancos. Em outra direção, podemos visualizar movimentos de ocupação de terra por um campesinato anteriormente estigmatizado. Mas o processo de luta contra as diferentes formas de expropriação, a luta para sua (re)produção social fez-se experiência e conhecimento. Assim, esse trabalhador se integrou a outras redes que lutam por uma "rerruralização", que significou o plantio de novas raízes, raízes de "muxuango". Esse foi o termo utilizado por Lamego (1946) para classificar o "caipira" que vivia no Vale do São João ${ }^{21}$ na década de 40.

O "rústico", o "rude", o "caipira" (cf. Candido, 2001) do Vale do São João mantém um movimento permanente de ocupação e expulsão, retomada e perda. Seja na forma de goitacá, seja na forma de subproletarizado, a história desses "muxuangos" representa a história fundiária brasileira em devir, pois corresponde a ciclos de concentração fundiária e ciclos de desconcentração, sem alterações radicais no regime de propriedade (Martins, 2003).

As diferentes conjunturas se desenham dinamicamente em variadas formas de conflito entre agentes e agências, uma tensão permanente acerca de direitos sobre a posse e a titularidade da terra. Esses projetos de rerruralizar tem como traço comum o enfrentamento de projetos colonizadores, que não podem ser concebidos de uma forma binária: atrasados ou modernos, ecológicos ou agrícolas, mas como expressão de conflitos territoriais. O desdobramento desses interesses se caracteriza pela intensa onda de conflitos e pelo gradativo avanço da urbanização sobre essas áreas, antes eminentemente agrícolas.

\footnotetext{
20 "Do ponto de vista dos agentes sociais relacionados ao agrofluminense, verificou-se um contramovimento que poderíamos designar como 'rerruralização' e que se estabelece em duas direções como reação à desagriculturalização. A partir dos anos 1980, aproximadamente, começa a ocorrer uma ocupação fundiária, em geral conduzida por uma classe média, ligada à produção agrícola, [...] e com suporte simbólico carregado de consciência ecológica. [...] De outro lado, verifica-se uma ocupação pelo movimento social organizado, que encontra resistência de todas as formas. (Ribeiro, 2005: 160) 21 "O pioneiro da charneca e que ainda ama a terra quase inútil. Ante a inexequibilidade da lavoura, amarra um anzol na ponta de uma linha ou mercadeja pelos centros urbanos os magros feixes de lenha que arqueiam o lombo das 'pulitanas' esquálidas. O habitante do deserto amplia o deserto." (Lamego, 1946: 17)
} 
A política desenvolvimentista dos governos militares teve como efeito um processo de "desagriculturalização" nas décadas de 1980/1990. A elevação da concentração fundiária e a urbanização do estado do Rio de Janeiro têm como sintoma e exemplo o fracasso da produção de arroz, a partir da abertura econômica, dentro de uma lógica neoliberal. Menezes (1999) demonstra que a década de 1990 é marcada tanto pelo sentimento de abandono da oligarquia nacional como pela redução da participação governamental na elaboração e execução da política agrícola como características da política neoliberal (Menezes, 1999).

O início dos anos 1980 foi marcado pela modificação de algumas tendências dominantes no período anterior, em especial devido ao enfraquecimento do regime militar. $\mathrm{O}$ processo de redemocratização foi contemporâneo ao nascimento do MST, à reorganização da Confederação Nacional dos Trabalhadores na Agricultura (Contag) e ao fortalecimento da Comissão Pastoral da Terra. Sob as bandeiras "Sem reforma agrária, não há democracia" e "A ocupação é a única solução", o Movimento dos Sem Terra, recém organizado no Estado do Rio de Janeiro, intensifica as ocupações. Segundo João Pedro Stédile, ao mesmo tempo em que aumenta o número de assentamentos pelo país, a própria elite rural se reorganiza. "Como o Estado não podia desencadear a repressão maciça, surgiu a [União Democrária Ruralista] UDR, como uma forma de organização do latifúndio." (Stedile \& Fernandes, 2012: 69).

A partir do início da década de 1980, a economia brasileira entrou em um longo período de estagnação econômica, em grande medida imposta pelo grande endividamento externo. A luta pela terra adquiriu então outro contorno, pois não se tratava mais de lutar contra a expulsão das terras, mas sim por alternativas de sobrevivência. Como destacam Medeiros e Leite (1999), o acampamento Campo Alegre (Nova Iguaçu) foi simbólico, pois não se tratava de recriar um modo "camponês", mas de buscar sobrevivência, conjugando o trabalho agrícola com outras atividades ou rendas. Essas novas dinâmicas do movimento social encontraram aliança no ressurgimento de lideranças camponesas pré-64, apoiadas pela Igreja.

Nesse primeiro momento de retomada das lutas, tanto o sindicalismo como o MST estavam ausentes ou fragilizados, e a ação do Governo do Estado do Rio de Janeiro (governo de Leonel Brizola), de realizar desapropriações por interesse social e constituir os assentamentos, colaborou para que o movimento ganhasse projeção e força. Mas como o MST/RJ entendia que o governo estadual "esvaziava e cooptava o movimento", não assumindo um papel de direção política, houve a criação de "condições para que não só o pessoal do Estado, mas 
também - e principalmente - os assessores da CPT/RJ ocupassem esse espaço" (Novicki, 1994: 78).

A política de desenvolvimento rural do Governo Brizola, na década de 1980, aconteceu em sintonia com o fim das grandes obras, que incluem a barragem, a drenagem e a retificação dos rios Aldeia Velha e São João. Inicia-se o processo de migração de trabalhadores rurais do Sul do país para o cultivo de arroz, estimulados, também pela iniciativa privada, atividade potencializada pelo programa federal Pró-Várzea, do qual o grileiro da fazenda Arizona se beneficiou. Entre o final da década de 1980 e o início da década de 1990, percebemos a confluência de um movimento em rota de colisão: o ressurgimento dos movimentos sociais e o ápice do processo de "modernização" da agricultura do Vale do São João.

Entre os anos de 1995 e 2003, sob o governo federal de Fernando Henrique Cardoso, que se apoiava ideologicamente na integração econômica através do "mercado", houve uma alteração importante de conjuntura. A política nacional de reforma agrária foi implantada para, mais do que uma reforma no regime de propriedade, permitir uma inclusão social ao capitalismo moderno. Para Martins (2003), essa política teve por objetivo, por meio da redistribuição de terras, ressocializar populações deixadas à margem do desenvolvimento econômico. Nesse sentido, a clientela da reforma agrária é tratada como uma clientela de cidadãos e legítimas (Martins, 2003: 38).

Uma ocupação em particular, organizada pelo MST e pela Fetag, merece destaque. Em 1997, os trabalhadores rurais ocuparam e construíram acampamento nas terras da Fazenda Sobara (Gleba Sul), entre as cidades de Casimiro de Abreu e Silva Jardim. A partir de mobilizações de sindicatos rurais e do MST, alguns ônibus fizeram um trajeto coletando as famílias que originariam a primeira ocupação. E entre as cidades podemos citar, de acordo com os relatos: Silva Jardim, Cabo Frio, Araruama, Casimiro de Abreu, Rio das Ostras, Macaé, Conceição de Macabu e Cachoeiras de Macacu. Segundo relato coletado em 2017: "mandaram o ônibus no dia 20 de junho de 97 , a noite juntamu todo mundo e viemos pra mundo a fora, sem saber pra onde ir. Viemos do lado de lá, viemos pela Amaral Peixoto. Entramos, quando foi de madrugada nós chegamos aqui” (Entrevistado B).

O público originário envolvido era diverso, com ou sem passagem pela agricultura, sendo que muitos tinham empregos urbanos e moravam na periferia dessas cidades. Pedreiros, eletricistas, marceneiros, seguranças e trabalhadores rurais compunham o coletivo de ocupação, como se pode perceber no seguinte depoimento de um dos ocupantes originários, que tinha sido guarda municipal: 
Foi uma passagem muito dura, cheguei a fazer uma ordem de despejo em Conceição de Macabu, mas cheguei lá e encontrei aquelas barraquinhas todas de plástico e fizemos o despejo. [...] E dentro dessa ocupação eu tinha um irmão [...] que eu cheguei lá que eu vi ele, eu peguei e chamei ele pra conversar. Ele pegou e falou pra mim, conversar com você pra que? Você do lado da justiça e nós no lado de cá da covardia. Eu falei não. Muita vez foi Deus que me enviou aqui no meio de ocês pra livrar vocês do mal que vocês podem passar aqui dentro. Porque aqui vou te contar, ninguém tem pena de ninguém não. Se balançar a bandeira eles entram derrubando tudo, acabando com tudo e vocês não vão ter peso pra aguentar, então era melhor vocês me ouvir e a gente entre num bom senso e chegar no oficial de justiça. Aí ele me levou lá numa barraca e conversamos. (Entrevistado B, entrevista realizada em 2017)

Esse relato representa uma mudança na vida que o direcionou para a ocupação de Sebastião Lan:

Cheguei em casa de noite eu pensei bem. É brincadeira, né?! Eu pobre precisando de terra, né, e lá tirar o povo da terra. Eu vou no outro dia, aí chegou o mineirinho e o amarelinho, que era do MST. Chegou lá e disse pra mim que tinha uma ocupação e tava precisando de mim pra fazer um trabalho. Eu disse, como eu vou fazer um trabalho se eu não entendo nada de ocupação. Aí levantei no outro dia e disse tá bom! Vocês podem vir que eu vou assumir, e fui na prefeitura e pedi baixa. Lá o delegado não queria negociar. [...] Aí com aquilo pedi baixa, ele não quis dar, deixei meus documentos lá e disse: a hora que ocês cismar me chamam porque eu não quero mais trabalhar. (Entrevistado B, entrevista realizada em 2017)

O entorno da Reserva Biológica foi não só alvo de um processo de grilagem de terras e disputas judiciais, mas também de uma reocupação pelo movimento social organizado, retornando a área para o domínio público através da gestão do Incra. A mobilização de trabalhadores pelo MST, Fetag e Sindicato de Trabalhadores Rurais de Cabo Frio culminou na reocupação de terras que "sobraram" da implantação da unidade de conservação. Os supostos "donos" se "beneficiaram" de investimentos públicos (retificação de rios e drenagem dos terrenos) somados à corrupção de agentes privados e públicos (latifundiários e grileiros).

Dia 21 de junho de 1997, surgiu o primeiro acampamento onde hoje se localiza o Assentamento Sebastião Lan I, com a mobilização de cerca de 300 famílias. A escolha do nome representa uma homenagem à memória do ex-presidente do Sindicato dos Trabalhadores Rurais de Cabo Frio, liderança assassinada no atual Assentamento Rural Campos Novos (Cabo Frio). Em resposta às ameaças e com a intenção de tornar pública a ocupação, houve uma marcha que saiu de Casimiro de Abreu, em julho de 1997, em direção à sede do Incra, no centro do Rio de Janeiro. Ao todo, 300 famílias permaneceram lá por 17 dias. Além das ameaças e da coação, a reação dos fazendeiros ocorreu, via Poder Judiciário para reintegração de posse, reivindicando as terras a partir de supostas atividades agropecuárias. 
Seis meses depois da primeira ocupação (Sebastião Lan, Gleba Sul), algumas famílias transferiram-se para o outro lado do Canal do Rio São João, na margem esquerda e estabeleceram o acampamento no chamado Brejão (Gleba Norte), que "pertencia" à Fazenda Arizona. Tanto a área ocupada da fazenda Sobara quanto a área ocupada da fazenda Arizona foram frutos de grilagem, terras incorporadas ilegalmente após a canalização do rio São João e do rio Aldeia Velha. Rios esses que eram limites naturais entre as fazendas e a Reserva Biológica que, canalizados, "aumentaram" as áreas das respectivas fazendas em detrimento da unidade de conservação.

Ainda em 1997, a possibilidade de ocupar outra área, identificada no Mapa como Ilha Tinguiba (e futuramente escolhida pelo movimento social como futuro Sebastião Lan III) surge como alternativa. Essa área "emergiu" após a construção da barragem de Juturnaíba, uma terra devoluta ilegalmente ocupada por alguns fazendeiros. A tentativa de ocupação foi assim relatada por um dos entrevistados:

Aquela área era melhor que o Sebastião Lan I e II, a gente já tava de olho [...] arrumamos cinco revólveres, espingarda, tinha muita gente... Derrubamos a cerca, colocamos cercado pra porco e começamos a arrumar as barracas [...] No dia seguinte, já tinha um e outro olhando a gente [...] Eles intimidavam e a gente também intimidava. Até que no início da tarde foi tiro de até metralhadora, a gente deixou tudo lá: porco, galinha, barraca, panela. Até roupa presa no arame farpado na hora da correria. (Entrevistado C, entrevista realizada 2017)

Outro entrevistado disse que o "confronto [foi] com polícia foi lá no Lan III [Ilha Tinguiba]. Tomei muita raça de tiro ali em cima, tivemu que recuá", (Entrevistado B, 2017). O total de famílias superava a capacidade do terreno ocupado (Gleba Sul - Sebastião Lan I). Depois de uma série de análises dentro do movimento de ocupação, e como que a Ilha Tinguiba apresentava forte resistência, houve a indicação para a ocupação da área conhecida como Gleba Norte (Sebastião Lan II), em "novembro de 1997 a gente pulou pra cá", atravessando o canal do rio São João em direção à Gleba Norte.

De acordo com entrevistas coletadas ao longo de 2017, para além da organização interna nos acampamentos (Lan I e II), a divisão entre a Federação dos Trabalhadores na Agricultura (Fetag) e o MST reduziu-se com o tempo, apesar do início formarem acampamentos distintos. Essas divisões, para alguns entrevistados, envolvia a organização entre coletivos internos, mobilizados em cada um dos municípios. De tal forma, podemos compreender o fato de que a maior parte daqueles que decidiram permanecer no Sebastião Lan I eram da mesma região (Cabo Frio e Rio das Ostras - devido ao acesso a esses municípios), enquanto 
aqueles que atravessaram o canal do São João para fundar o acampamento de Sebastião Lan II eram, principalmente, de Macaé, Conceição de Macabu, Cachoeiras de Macacu e Casimiro de Abreu. A identidade regional era mobilizada nas primeiras disputas pela liderança do acampamento, como se pode ver no relato de um dos moradores de Sebastião Lan II:

A gente precisava de bandeiras, cada bandeira era importante, fazia impacto [...] mas a gente se organizava mesmo pelas cidades, quem era de Conceição era de Conceição, o pessoal de Cabo Frio era mais unido com Cabo Frio, tinha o grupo de Macaé... Às vezes eu levantava a bandeira da Fetag, às vezes do MST... (Entrevistado C, entrevista realizada em 2017)

FigURA 2 - NA IMAGEM DE SATÉLITE É POSSÍVEL IDENTIFICAR A LOCALIZAÇÃO DOS PROJETOS DE

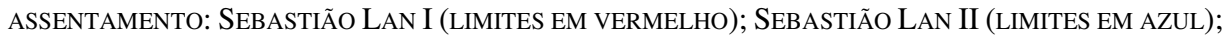
E SEBASTIÃo LAN III (LIMITES EM VERDE).

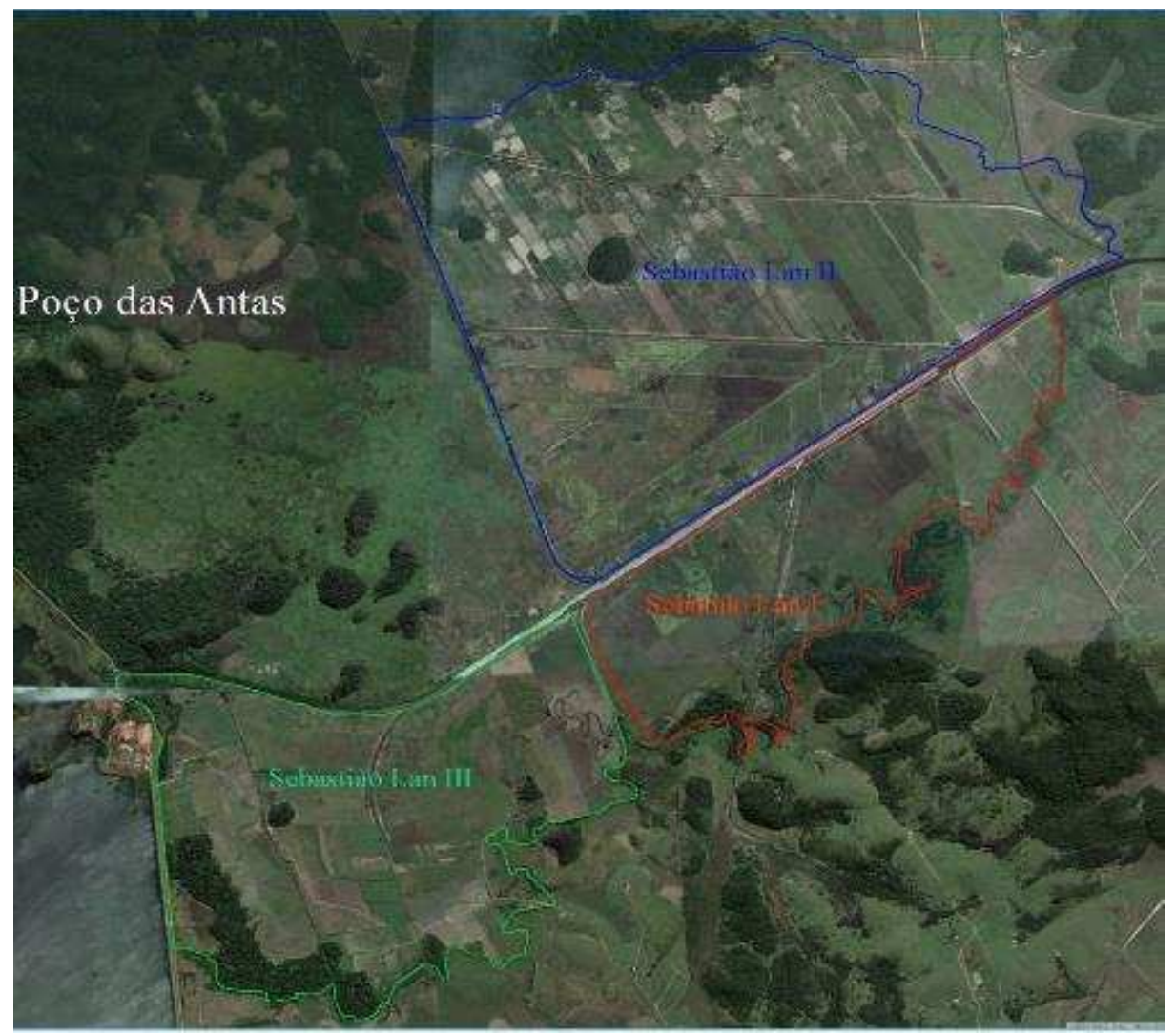

Fonte: Incra/RJ 
A busca de legitimidade era uma forma de proteção contra as violências e ameaças sofridas nos acampamentos. A definição sobre qual área ocupar no recém-território Sebastião Lan passou pela avaliação de forças disponíveis e forças contrárias - mas, sobretudo, pela avaliação das próprias ilegalidades dos grandes fazendeiros. Num movimento contra-hegemônico, por mais "ilegal" que significasse a ação, o movimento social organizado revelava contradições entre o sistema jurídico/legalidade e a dinâmica social. $\mathrm{O}$ ato de ocupar revelou uma propriedade privada que foi fruto de um processo de grilagem de terras públicas. Dessa forma, denunciava-se o silêncio de autoridades, que permitiram a apropriação privada de recursos públicos através de obras, financiamentos e créditos. Eis que a ocupação se transformou em polêmica jurídica, dada sua fronteira tênue entre a legalidade e a ilegalidade, que, por fim, culminou no retorno das terras públicas para o controle do Estado.

Por enquanto, estavam demarcadas as diferenças, que se consolidarão no acampamento/assentamento Sebastião Lan I (Gleba Sul) e no acampamento Sebastião Lan II (Gleba Norte), também conhecido como Brejão. Os canais de drenagem, construídos pelo extinto DNOS com recursos públicos, são utilizados pelas famílias para limitar e organizar os lotes de produção/ocupação. Mas a definição de quais lotes ocupar passou a ser um desafio interno de organização, pois, logo após a ocupação do acampamento Sebastião Lan II, houve intensas chuvas e alagamentos, que provocaram um primeiro esvaziamento de famílias ocupantes:

No final de 1997, quando mudou pra cá caiu água. Choveu sem parar, emendou pra dezembro chovendo, chovendo, chovendo, isso foi encharcando, encharcando de uma maneira e foi ficando feio [...] Eu, na época, com criança pequena [...] olha, enfim, o MST pra vim aqui pra socorrer a gente saíram de barco lá pela BR e vieram de barco pelo rio Aldeia, desceram de barco, aí falou o seguinte pra gente: que quem tivesse com criança pequena pra esperar a água baixar que fosse. Que quem quisesse ficar aqui, que ocupasse as casinhas que tinha aí. Olha só a doideira: nessa daí eu fui pra fora, fiquei lá pra fora um tempo. (Entrevistado C, entrevista realizada em 2017)

Enquanto parte dos ocupantes foi obrigado a sair por causa das chuvas, pela busca de emprego ou em atividades do próprio MST, um grupo se organizou para ocupar os melhores lotes, que não inundaram durante as chuvas. A ausência de algumas lideranças e a diversidade entre os ocupantes criou um cenário de conflito interno, que ameaçou a organização do acampamento. A falta de um sorteio amplo gerou o sentimento de que houvera traições internas, percepções presentes até hoje quando se relata aquele momento.

O pessoal tinha invadido tudo aí, tava repartindo a terra toda e já tinham ocupado, escolheram os melhores lotes. Dona $\mathrm{X}$ aí foi tudo golpe, o Y foi tudo golpe, finado $\mathrm{W}$ foi golpe, $\mathrm{Z}$ que fez o motim todo, pegaram os melhores lotes. Os lotes mais altos tinham 
tudo, tinha jiló, banana, tinha quiabo, tinha tudo. Expulsaram os meeiros, os meeiros de arrendatários que o Incra considerou que ia assentar também. Eles estavam unidos e expulsaram esses caras na marra pra fora. Invadiram o lugar, os lotes com plantação. Isso na chuva! E aqueles que vinham chegando de volta, que as águas foi baixando, que faziam pressão aí eles iam indicando o lote. E eles ainda pediam vantagem, foi aí que eu voltei com tudo pra cá. Aí foi minha primeira história nesse acampamento de luta, assim. De enfrentamento com o povo mesmo. (Entrevistado C, entrevista realizada em 2017)

Nesse momento inicial, houve retaliações do fazendeiro, com a destruição de uma infraestrutura (pontes e rede elétrica), o que dificultava a circulação dos trabalhadores. Ações judiciais e conflitos com funcionários da fazenda e arrendatários compunham um cotidiano de luta pela permanência na terra ocupada. Após alguns meses, o Incra realizou um primeiro cadastro dos acampados, já com parecer favorável da justiça. Finalmente houve o reconhecimento da justiça de que a terra era do instituto de reforma agrária. Assim, as Glebas Norte e Sul ficaram disponíveis para a implantação de projetos de reforma agrária.

O Brejão (área do Sebastião Lan II) corresponde a uma área impactada pela retificação dos rios Aldeia Velha e São João. Originalmente inundada, "um pântano" (segundo relato de antigos moradores), em que os processos de dragagem e drenagem permitiram sua exploração econômica. Essa porção de terras foi objeto de grilagem pelos fazendeiros e, finalmente, ocupadas pelo movimento social organizado. É uma área cujo solo de turfa emergiu das áreas de mata ciliar drenadas, rico em matéria orgânica. Outra característica é o alto grau de combustão da terra, sendo possível assistir ainda hoje à formação de pequenas nuvens de fumaça no meio de uma plantação de aipim, por combustão espontânea. Com o fracasso do arroz e o uso depois pouco otimizado, é relevante citar o enorme passivo ambiental criado pelo antigo latifundiário da região.

Mas a situação de Sebastião Lan I e II não é única. Há, no entorno da Reserva Biológica de Poço das Antas outros projetos de colonização e regularização fundiária. Como da Fazenda Aldeia Velha, que originou o Assentamento Aldeia Velha. Ou o projeto criado pelo Incra em 1981, que se origina de trabalhadores rurais e trabalhadores da Leopoldina (ferrovia que cortava a área), removidos para a instalação da unidade de conservação. E de uma antiga propriedade, pertencente à Cia Açucareira Paraíso, desapropriada em 1994, originou o Projeto de Assentamento Cambucaes, criado em 1995 para 106 famílias. 


\section{CONSIDERAÇÕES FINAIS: A EMERGÊNCIA DO AMBIENTAL COMO PROBLEMA PARA A REFORMA AGRÁRIA}

Pode-se facilmente constatar o quanto a área do entorno da unidade de conservação se constituiu em território de disputa, seja por agricultores familiares e trabalhadores da região, seja por latifundiários. Após a vitória do movimento social, no caso da ocupação de Sebastião Lan II, o Ministério Público Federal, o Ibama e as ONGs ambientalistas promoveram duas Ações Civis Públicas (ACP), em 1998, com o intuito de impedir que o Incra promovesse assentamentos rurais no entorno da Reserva Biológica. As ACPs visavam recompor danos morais e patrimoniais referentes a questões ambientais, bem como tutelar interesses coletivos e difusos, entre outras hipóteses. Utilizou-se, para tanto, a Resolução Conama 13/90, que estabelece a chamada zona tampão, assim descrita:

Art. $1^{\circ}$ - O órgão responsável por cada Unidade de Conservação, juntamente com os órgãos licenciadores e de meio ambiente, definirá as atividades que possam afetar a biota da Unidade de Conservação.

Art. $2^{\circ}$ - Nas áreas circundantes das Unidades de Conservação, num raio de dez quilômetros, qualquer atividade que possa afetar a biota deverá ser obrigatoriamente licenciada pelo órgão ambiental competente.

Por situar-se ao lado de uma reserva biológica, o acampamento Sebastião Lan II tem seus conflitos socioambientais ligados a uma dinâmica judicial que ultrapassa as esferas do Judiciário, da unidade de conservação ou de uma agricultura moderna. Por isso há, pelo menos, dois momentos com espaços de disputas não resolvidos. Primeiro, ao longo das décadas de 1980 e 1990, quando contemplávamos um conflito entre os grandes proprietários e os trabalhadores rurais. E, posteriormente, o conflito aparentemente (in)superável, e ideologicamente construído, entre concepções de uso da terra, que envolvem dois órgãos do Estado, uma autarquia fundiária e o Ibama.

Durante os trabalhos que resultaram no Laudo Multidisciplinar em Conflito Socioambiental, o levantamento processual aponta uma mudança nos sujeitos envolvidos nas demandas judiciais. Pereira (2008) organiza os dados relativos à mudança da seguinte forma: década de 1980, disputas entre Estado e Fazendeiros; década de 1990, disputas entre Estado e trabalhadores rurais sem terras; a partir de 2000, disputas entre Ibama e Incra.

Em outra ACP, a Associação dos Amigos do Rio São João - Amirio apresentou o mesmo objeto de contestação, ao alegar riscos ambientais resultantes do assentamento rural. A primeira reação do Judiciário - tanto da Justiça Estadual quanto na Federal - foi acatar de maneira liminar o pedido dos deman- 
dantes, com base na necessidade de prevenir um suposto dano irreparável ao equilíbrio da reserva. As denúncias e a ação de uma rede conservacionista, agenciadas pelo Ibama e pela Associação do Mico-Leão-Dourado, iniciaram um processo de transformação de um conflito fundiário em um conflito ambiental.

Tensionados pela questão ambiental, o MST do Rio de Janeiro promoveu discussões e alianças com setores do movimento ambientalista ${ }^{22}$. Em agosto de 1998, as entidades envolvidas produziram uma carta aberta para pedir atenção especial do Poder Judiciário, sobre a situação do entorno da Reserva Biológica de Poço das Antas. Nesse documento, as entidades reafirmaram a reforma agrária como condição para proteção ambiental, denunciando que nenhuma ação semelhante fora movida contra os fazendeiros ou grileiros de terras que atuavam na região. Na carta, as entidades posicionam-se contra a interpretação da Resolução Conama ${ }^{\circ} 13 / 90$, que, segundo o Ministério Público, proibia os assentamentos rurais.

[...] Houve um entendimento equivocado da legislação ambiental em vigor no país, uma vez que a Resolução Conama $n^{\circ}$ 13/90 não proíbe assentamentos humanos e atividades produtivas como agricultura, na área circundante às Unidades de Conservação. Na verdade, a legislação prevê a necessidade de obtenção de licenciamento ambiental, junto aos órgãos competentes... ${ }^{23}$ (Carta aberta do MST e ambientalistas, 1998)

Essa mesma carta destacava o compromisso firmado entre a Coordenação Estadual do MST e os movimentos ambientalistas ${ }^{24}$, intitulado "Pacto Chico Mendes". Assinado em novembro de 1997, esse compromisso já era uma resposta do movimento social às críticas diante da ocupação de área vizinha a uma reserva biológica com reconhecimento internacional. Além do compromisso de reflorestar as áreas degradadas, o movimento se comprometia a não fazer uso de agrotóxicos, realizar estudos técnicos, respeitar a legislação ambiental e combater práticas predatórias, como o desmatamento e a caça. Entre os objetivos do Pacto Chico

\footnotetext{
${ }^{22}$ Podemos citar: Os Verdes - Movimento de Ecologia Social; Comissão de Defesa do Meio Ambiente da ALERJ; Cooperativa Multi-Profissional Ofícios da Terra; e APEDEMA/RJ (Assembléia Permanente de Entidades em Defesa do Meio Ambiente).

${ }^{23}$ Carta aberta do MST e entidades ambientalistas ao Ministério Público Federal e à Justiça Federal sobre a compatibilização da reforma agrária com a proteção do meio ambiente, agosto de 1998.

${ }^{24}$ As seguintes entidades ambientalistas assinaram o Pacto Chico Mendes: Coordenação da Assembleia Permanente das Entidades em Defesa do Meio Ambiente, Os Verdes - Movimento de Ecologia Social, Defensores da Terra, Associação Fluminense de Engenheiros e Arquitetos (AFAE), Associação de Engenheiros Agrônomos do Estado do Rio de Janeiro (AEARJ), Grupo de Agricultura Ecológica (GAE, vinculado à Universidade Federal Rural do Rio de Janeiro), Federação dos Estudantes de Agronomia do Brasil - Regional III, AMA-BARRETO (Niterói), Movimento de Resistência Ecológica (MORE), Centro Acadêmico de Geografia (UERJ/FFP), Comissão de Defesa do Meio Ambiente da ALERJ e a Comissão Nacional de Meio Ambiente da CUT.
} 
Mendes também constava a possibilidade de "garantir aos ambientalistas amplo acesso para comprovação dos cuidados ambientais, objeto deste compromisso" 25 .

Aparece para os pesquisadores que acompanhavam o debate uma possibilidade de construção de um acerto harmônico, no sentido de criar um projeto concreto de desenvolvimento sustentável no Lan II. O local é de interesse especial para a reprodução e expansão da reserva, além de servir como proteção ao entorno degradado pelas queimadas, pelo pasto e pelas monoculturas de arroz. A ocupação demonstrava uma recuperação produtiva do solo castigado, além de não interferir na reprodução do mico-leão-dourado e da fauna da reserva de forma positiva.

O caso descrito ainda está em curso, o que demonstra uma grande capacidade de resistência desses trabalhadores rurais. E, ainda mais, que a agricultura familiar tem potencialidades que não podem ficar reféns de lógicas economicistas ou produtivistas, como apontam Carneiro e Maluf (2003). Faz-se necessária uma ressalva sobre o movimento constante de reconstrução social da agricultura, que estimula a produção de alimentos e que seja portadora de benefícios culturais e ambientais. Em cada "pé de sonho" plantado em Sebastião Lan II surge uma sombra que recupera a antes castigada terra, brotam alimentos, nascem crianças, formam-se famílias, retornam as festividades. Há dentro de cada simples casa construída sem o auxílio dos governos, a esperança de que das mãos dos trabalhadores nascerá um novo rural, uma nova agricultura. Para essa nova agricultura florescer precisou combinar luta e utopia.

Nos interstícios do Estado e do mercado há uma reforma agrária em gestação constante. Se de um lado há um movimento de concentração de terra (desagriculturalizando-a), do outro, nota-se um movimento de democratização das terras (rerruralizando-as). A especulação imobiliária e os limites ambientais do "mundo moderno" deixaram de ser problemas restritos a espaços unicamente urbanos ou rurais. Da mesma forma, as bandeiras da terra e da moradia, assim como as bandeiras de luta contra os autoritarismos, fazem da experiência cotidiana de luta dos trabalhadores rurais uma experiência de uma classe social.

Diante de autoritarismos não declarados ou silenciosos, de um sistema econômico que produz miséria e violências, identificamos pequenas trilhas de um caminho sem uma direção preconcebida. Se o processo de acumulação capitalista e expropriação aparecem como uma variável constante na história e no presente do Vale do São João; há, também, algumas invariáveis ou regularidades, como as mãos calejadas e perfumadas com o cheiro da terra e do trabalho, que seguem resistentes na (re)produção social da vida.

${ }^{25}$ Pacto Chico Mendes, Rio de Janeiro, novembro de 1997. 


\section{BIBLIOGRAFIA}

Binzstock, J. (1998). Capitalismo Autoritário e a Questão Ambiental no Vale do São João. In A. M. Motta Ribeiro et al. (Eds.), Campo Aberto - O rural no Estado do Rio de Janeiro (pp. 327-334). Rio de Janeiro, Brasil: Contracapa.

Bourdieu, P. (2014). Sobre o Estado: cursos no Collège de France (1989-92). São Paulo, Brasil: Companhia das Letras.

Brandão, C.R. (1981). Pesquisa Participante ( $3^{a}$ edição). São Paulo, Brasil: Brasiliense.

Brandenburg, A. (2005). Ciências Sociais e Ambiente Rural: principais temas e perspectivas analíticas. Revista Ambiente e Sociedade, 8(1), pp. 51-64. https://doi.org/10.1590/S1414753X2005000100004

Candido, A. (2001). Os parceiros do rio bonito: estudo sobre o caipira paulista e a transformação dos seus meios de vida. São Paulo, Brasil: Duas Cidades; Ed. 34.

Carneiro, M. J., \& Maluf, R. S. (Eds.). (2003). Para além da produção: multifuncionalidade e agricultura familiar. Rio de Janeiro, Brasil: MAUAD.

Citricultura tem boas perspectivas de se desenvolver. (1973, Setembro 29). Jornal do Brasil, p.7.

Convênio com DNOS dará a rio São João e afluentes leito dragado e barragens. (1971, Agosto 4) Jornal do Brasil, p.23.

Crosby, A. (2011). Imperialismo Ecológico: A expansão biológica da Europa 900-1900. São Paulo, Brasil: Companhia das Letras.

Cunha, S. B. (1995). Impactos das obras de engenharia sobre o ambiente biofísico da bacia do Rio São João. Rio de Janeiro, Brasil: Instituto de Geociências.

Dean, W. (1996). A Ferro e Fogo: a história e a devastação da Mata Atlântica brasileiras. São Paulo, Brasil: Companhia das Letras.

Delgado, G. C. (2005). A Questão Agrária no Brasil, 1950-2003. In L. Jaccoud (Ed.), Questão Social e Políticas Sociais no Brasil Contemporâneo (pp. 51-90). Brasília, Brasil: IPEA.

Desmatamento (1971, Agosto 5). Jornal do Brasil, p. 31.

Geiger, P., \& Mesquita, M. (1956). Estudos rurais da Baixada Fluminense (1951-53). Rio de Janeiro, Brasil: IBGE.

E. do Rio faz projeto integrado. (1973, Julho 23). Jornal do Brasil, p. 18.

Estado do Rio desapropria área para manter suas florestas. (1970, Setembro 6). Jornal do Brasil, p. 7.

Estado tem verbas para recuperação do Vale do São João. (1973, Dezembro 30). Jornal do Brasil, p. 7.

Gonçalves Neto, W. (1997). Estado e Agricultura no Brasil: política agrícola e modernização econômica brasileira. São Paulo, Brasil: Hucitec.

Governo do Estado do Rio de Janeiro. (1970, Março 2). Estamos fazendo tudo para acabar com o homem da roça. Jornal do Brasil, p. 5.

Graziano da Silva, J. (1982). A modernização dolorosa: Estrutura agrária, fronteira agrícola e trabalhadores rurais no Brasil. Rio de Janeiro, Brasil: Zahar.

Haesbaert, R. (2004). O Mito da Desterritorialização: do "fim dos territórios" à Multiterritorialidade. Rio de Janeiro, Brasil: Bertrand Brasil. 
Homem tenta reparar danos que causa à natureza. (1972, Junho 11 e 12). Jornal do Brasil, p. 18.

IBDF acha ser armado com flecha. (1973, Julho 19). Jornal do Brasil, p. 14.

Informe RJ. (1973, Outubro 14). Jornal do Brasil, p. 4.

Lamego, A. R. (1945). O homem e o brejo. Rio de Janeiro, Brasil: IBGE.

Lamego, A. R. (1946). O homem e a restinga. Rio de Janeiro, Brasil: IBGE.

Madeira Filho, W., Motta Ribeiro, A. M. Pereira, M. C. de, \& Prata Filho, D. de A. (Eds.). (2007). Laudo multidisciplinar em conflito sócio-ambiental: o caso da reforma agrária no entorno da Reserva Biológica de Poço das Antas (Série Pesquisas n²). Niterói, Brasil: PPGSD-UFF.

Martins, J. d. S. (1981). Campesinato e Política no Brasil. Petrópolis, Brasil: Vozes.

Martins, J. d. S. (2003). O Sujeito Oculto: ordem e transgressão na reforma agrária. Porto Alegre, Brasil: Editora UFRGS.

Marx, K. (1977). Formações Econômicas pré-capitalistas. Rio de Janeiro, Brasil: Paz e Terra.

Medeiros, L. S. de, \& Leite, S. (1999). A Formação dos assentamentos rurais no Brasil: processos sociais e políticas públicas. Porto Alegre; Rio de Janeiro, Brasil: Ed. Universidade; UFRGS; CPDA.

Mendonça, S. R. (1997). O ruralismo brasileiro (1888-1931). São Paulo, Brasil: HUCITEC.

Menezes, F. (1999). Política agrícola e o Governo Collor. Rio de Janeiro, Brasil: Fase.

Moreira, R. J. (1995). Renda da natureza e territorialização do capital: reinterpretando a renda da terra na competição intercapitalista. Estudos Sociedade e Agricultura, (4): pp. 89-111.

Nem Reserva detém desmatamento. (1975, Março 7). Jornal do Brasil, p. 13.

Novicki, V. d. A. (1994). Governo Brizola, movimentos de ocupação de terras e assentamentos rurais no Rio de Janeiro (1983-1987). In L. S. de Medeiros et al. (Eds.), Assentamentos Rurais: uma visão multidisciplinar (pp. 69-86). São Paulo, Brasil: Editora da Universidade Estadual Paulista.

Novo Estado do Rio poderá tirar melhor proveito de uma agricultura racional. (1974, Setembro 22). Jornal do Brasil, p. 22.

NMSPP (Núcleo de Pesquisa e Documentação sobre Movimentos Sociais e Políticas Públicas no Campo). (2005). Conflitos por terra e repressão no campo no estado do Rio de Janeiro (1946-1988) - (Relatório de Pesquisa). http://www.nmspp.net.br/arquivos/para_leitura/camponeses_e_ditadura/Conflitos\%20por\%20Terra\%20e\%20Repressao\%20no\%20Campo\%20no\%20Estado\%20do\%20Rio\%20de\%20Janeiro\%20-\%201946-1988.pdf

O'Dwyer, E. C. (1982). Expropriação e Luta dos Camponeses Fluminense. Revista da ABRA, 12(2), pp. 13-25.

Palmeira, M. (1989). Modernização, Estado e Questão Agrária. Estudos Avançados, 3(7), pp. 87-108.

Palmeira, M. (1994). Burocracia: política e reforma agrária. In L. Medeiros et al. (Eds.), Assentamentos rurais: uma visão multidisciplinar (pp. 49-65). São Paulo, Brasil: Editora da Universidade Estadual Paulista. https://doi.org/10.1590/S0103-40141989000300006

Palmito será aproveitado em Casimiro. (1973, Agosto 12). Jornal do Brasil, p. 7. 
Pereira, M. C. de B. (2008). Reforma Agrária e Meio Ambiente: desafios e possibilidades em torno de conflitos envolvendo assentamentos rurais/INCRA e reserva biológica/IBAMA. Floresta e Ambiente, 14(2), pp. 49-63.

Produção no Vale S. João é estimulada. (1973, Julho 15). Jornal do Brasil, p. 7.

Região abandonada abastecerá o Rio. (1973, Dezembro 22). Jornal do Brasil, p. 15.

Ribeiro, A. M. (2005). Desagriculturalização. In M. Motta (Ed.), Dicionário da Terra (pp. 158-161). Rio de Janeiro, Brasil: Civilização Brasileira.

Ribeiro, A. M. (2007). Reflexões metodológicas: a produção do laudo multidisciplinar sobre conflito agrário ambiental no entorno da rebio poço das antas - uma abordagem marxista. https://anpuh.org.br/uploads/anais-simposios/pdf/2019-01/1548210414_a67d69905173601c47e6f7bdf1889c27.pdf

Seva, J. T. (2008) Classes patronais rurais e conflitos sociais: Um estudo sobre as ações das organizações patronais rurais frente à questão ambiental (dissertação de mestrado). Rio de Janeiro, Brasil: Universidade Federal Rural do Rio de Janeiro.

Stedile, J. P., \& Fernandes, B. M. (2012). Brava gente: a trajetória do MST e a luta pela terra no Brasil. São Paulo: Expressão Popular, Fundação Perseu Abramo.

Técnicos indicam no Estado do Rio problemas de distribuição de terra. (1973, Setembro 27). Jornal do Brasil, p. 27.

Vale do São João tem só culturas típicas e será área de hortigranjeiros. (1973, Agosto 19). Jornal do Brasil, p. 7. 